in the country and every group within the forest related complex of the North American continent.

The Forest History Collection at Yale is under the direction of Elwood R. Maunder, Executive Director of the Forest History Society, Inc., and Curator of Forest History on the University faculty. The collection is housed in Sterling Memorial Library.

\title{
FORESTRY MEMORIAL SCHOLARSHIP TORONTO
}

The President of the University of Toronto, Dr. C. T. Bissell announced that the Senate of the University had awarded a Forestry Memorial Scholarship of the value of \$200 for the session 1966-67 to Mr. Donald Wayne Gilmore, First Year student in the Faculty of Forestry.

The scholarship was awarded on the basis of his standing in the Ontario Grade XIII examinations last June.

Donald Gilmore is 18 years old and is the son of Mr. and Mrs. K. G. Gilmore of 39 Anndale Rd., Scarborough, Ont.

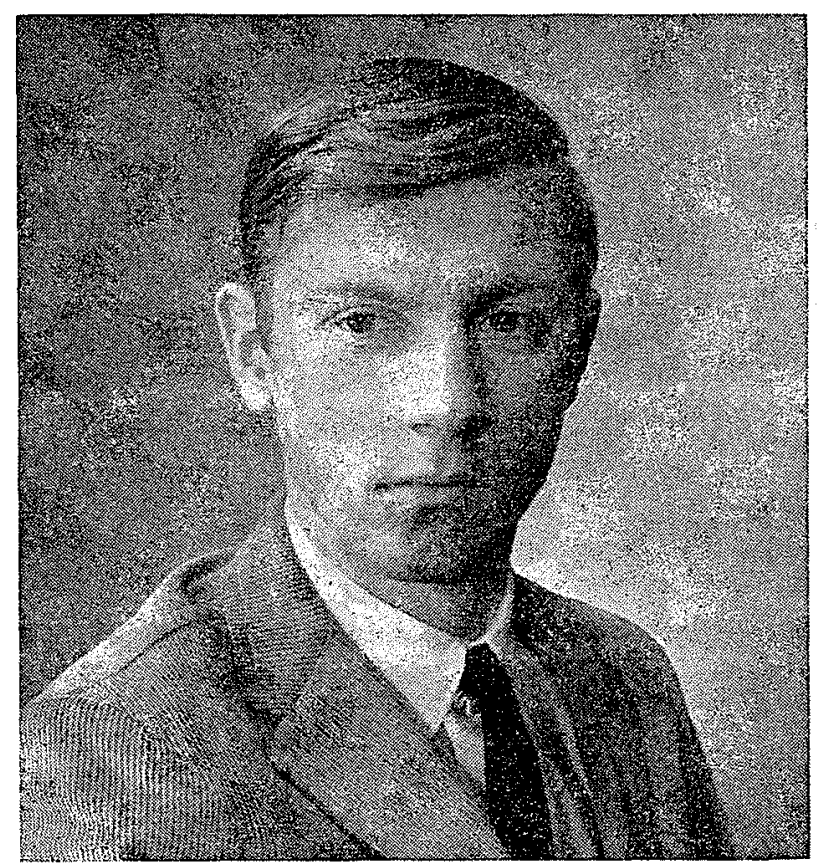

